\title{
Rich Merzoug and Afilou N'Khou Veins of the Oumjrane Deposit (Example of Oriental Anti-Atlas Copper Mineralization)
}

\author{
Wafik Amina (Professor)
}

Faculté des Sciences Semlalia/ Université Cadi Ayyad, Département de Géologie, DLGR, URAC 43, Marrakech, Morocco

\author{
Fettah Hicham (Geologist) \\ Rakhiss Lahcen (Geologist) \\ Ouadjou Abdelmalek (Geologist)
}

Compagnie Minière de Bleida, Groupe Managem, Twin Center,

Casablanca, Maroc

doi: 10.19044/esj.2017.v13n18p251 URL:http://dx.doi.org/10.19044/esj.2017.v13n18p251

\begin{abstract}
The geological study of the Oumjrane region (Anti-Atlas oriental), carried out within the Oumjrane mining company (CMO), with a view to a detailed study of the two copper strands Rich Merzoug and Afilou N'Khou , So a mapping of ground was made preferably for localization of the different facies and geological structures, with sampling of our magmatic rocks, following a microscopic study. These are dolerite, gabbro to olivine, basalt, the latter are located respectively south of the three exploited veins, Bounhass vein, Afilou N'Khou vein, and Rich Merzoug's veins. A detailed study of the latter two veins in the second Bani Ordovician quartzite sandstone series will lead to the identification of four hydrothermal stages responsible for the emplacement of the mineralization: stage 1 to calcite siderite, stage 2 Pyrite arsenopyrite, stage 3 galena barite, and stage 4 with chalcopyrite, are followed by supergene stage due to the alteration of copper sulphides. The Oumejerane ore deposits shows lateral zonation from SW $(\mathrm{Cu})$ to $\mathrm{NE}(\mathrm{Cu}-\mathrm{Pb}-\mathrm{Ba})$ and $(\mathrm{Cu}-\mathrm{Ba})$, wich underligne temperature decresing from SW to NE.
\end{abstract}

Keywords: Oumejerane, Ordovician- Copper, hydrothermal, veins

\section{Introduction}

Since the end of Proterozoic times, southern Morocco is connected to the West African Craton. This craton occupies almost all of West Africa and 
consists of granitoids, gneisses and a complex series of older metamorphic rocks attributed to the Eburnian orogeny at about $2000 \mathrm{Ma}$ (Burkhard, et al., 2006). The Anti-Atlasic lands at the northern edge of the West African craton are represented in the form of a vast relief that extends parallel to that of the High Atlas. They are mainly composed of a Paleozoic cover, resting on ancient Precambrian terrains, which appear in buttonholes. These AntiAtlasian territories are subdivided into three zones, western, central and eastern, whose facies are different from one zone to another. The latter, which represents the site of my final project, is formed by Paleozoic terrains in the form of Cuestas based on a Neoproterozoic age base, which represent the encasing of a polymetallic mineralization generally vein. The main ones are: (El Hamada fluorite seams, Boumadine polymetallic seams, Tiouit polymetallic seams, Bouskour's copper-bearing seams, and Oumjrane's copper-bearing veins). A few datas are availlable on south-oriental province of Morocco, for example Oumejeran district. The aims of our work is to study and class this district.

\section{Geographical location}

Le gisement d'Oumjrane est situé dans la partie Est de l'AntiAtlas oriental, à environ $124 \mathrm{~km}$ de Nkob suivant la route reliant Ouarzazate Agadir-Tazarine, à environ 70 km (à vol d'oiseau) au nord de Zagora, sur la route reliant Ouarzazate, Agdz et Errachidia, et à $50 \mathrm{~km}$ (à vol d'oiseau) d'Alnif.

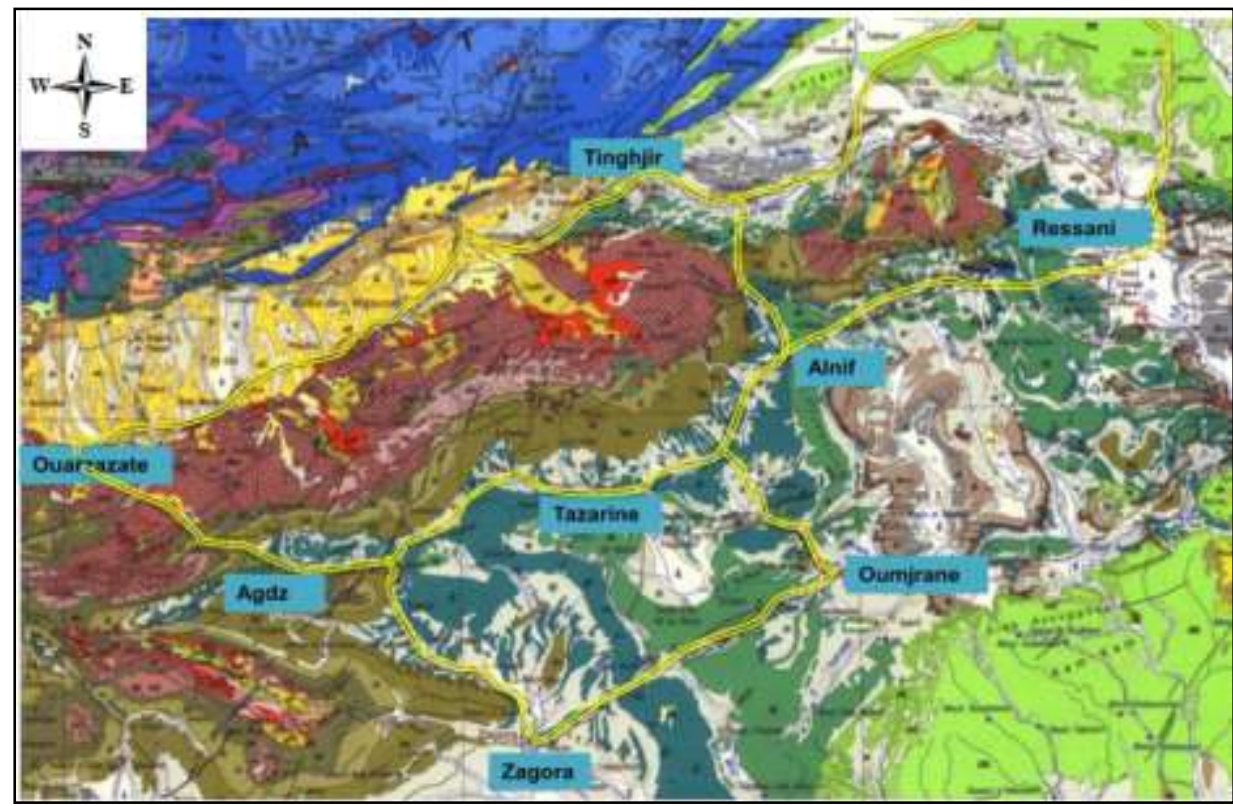

Figure 1. Geographical location of the Oumjrane deposit on the geological map of Morocco $(1 / 500000)$ 


\section{Geological setting}

The area of Oumjrane is located in the Anti-Atlasic area bounded on the north by Hssy'a, on the west by Taghbalet, on the south by the Graben of Zagora and on the east by the plain of Maider. The vein district of Oumjrane is encased in the Palaeozoic sandstone formations of the 2nd Bani, affected by a tectonic plague and brittle Hercynian.

\section{The Ordovician}

In the Eastern Anti-Atlas, the Ordovician formations were subdivided into four great groups defined by (Choubert, 1943): (Fig. 2)

Shale of Feijas extends, the sandstones of the 1st Bani, the schists of Ktaoua, and the Sandstones of 2nd Bani.

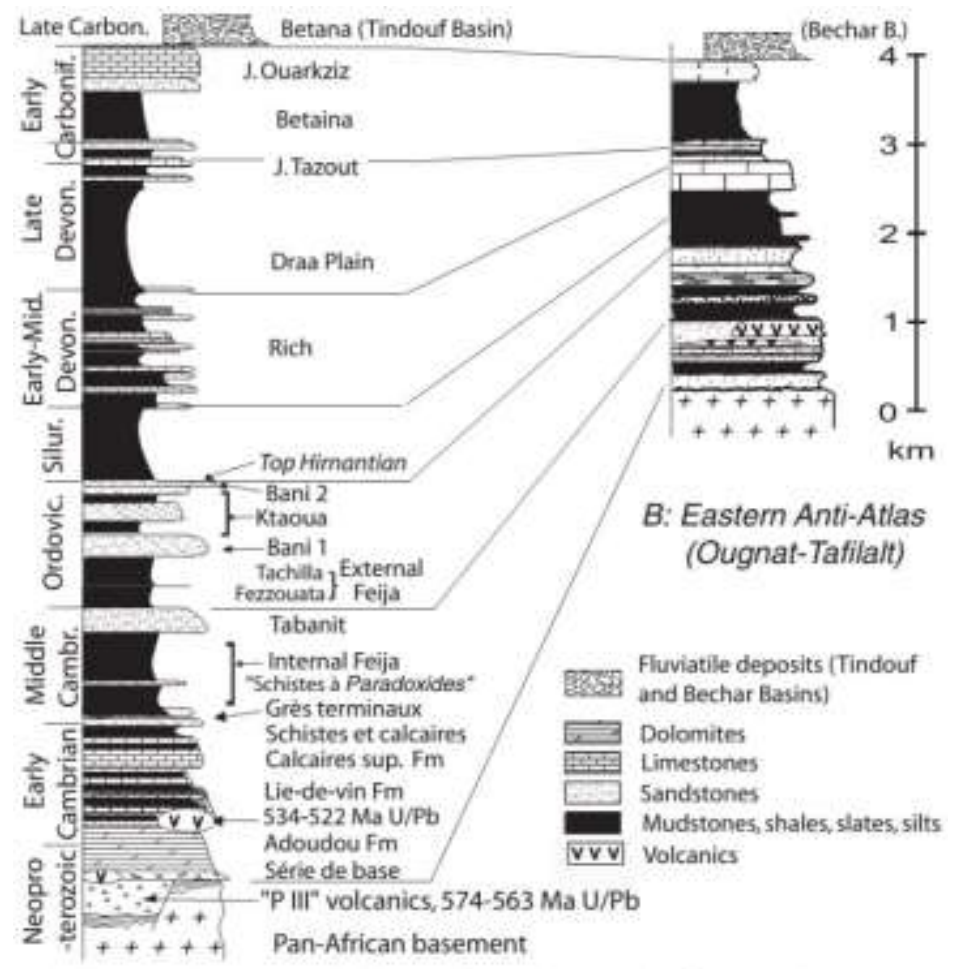

A: Western Anti-Atlas (J. Bani - Draa Plains - J. Ouarkziz)

Figure.2. Synthetic lithostratigraphic log of the Palaeozoic terrains of the Anti Atlas. (A) the

Western Anti-Atlas, according to Helg et al. (2004). (B) the Eastern Anti-Atlas (OugnatTafilalet), according to Baidder et al. (2008). The formations presented in black correspond to horizons of possible detachments during the folding. (A and B) Modified by Michard et al (2008)

In the study area, the Ordovician marks the main elements of the Palaeozoic cover, it is materialized by folded sandstone layers intersected by the mineralized veins. These sandstone layers of the mineralization attributed 
to the formation of the 2nd Bani are affected by fracturing (imbrication) at the hinges of the anticlines (Fig. 3A). They also show compressed nodular structures (Fig.3 B).
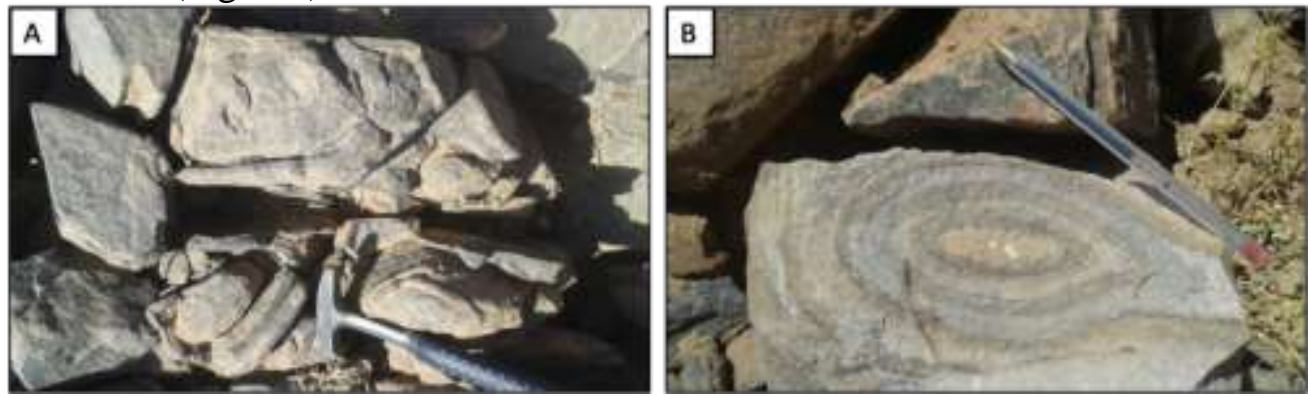

Figure.3. Sedimentary structures of sandstone (A) fracturing; (B) nodulation

\section{The Silurian}

The Silurian rests in angular discordance on the Ordovician formations of the 2nd Bani (Baidder, 2007), in the study area it rarely appears in depressions dug between the Ordovician sandstone formations of Afilou N'Khou and the Devonian formations further south, In the form of more or less pyritic black schist to graptoliths.

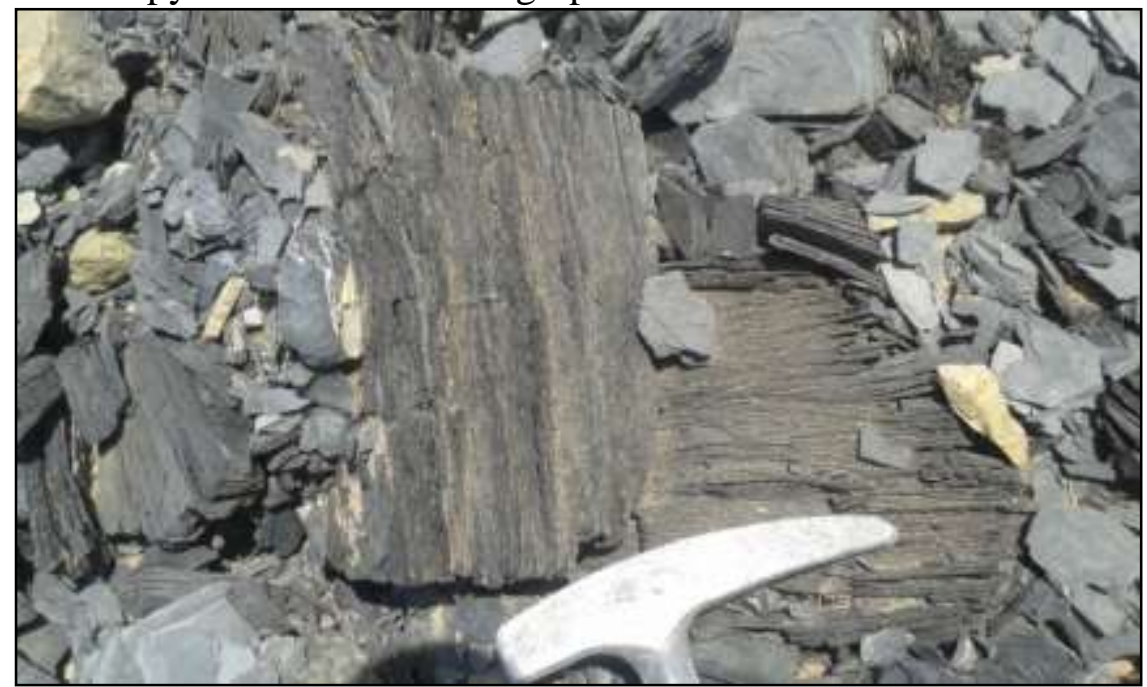

Figure 4. Silurian shales (photo taken from Afilou N'Khou heaps)

\section{The Devonian}

The Devonian in the study area and in the Eastern Anti-Atlas in general, marks a transgressive period. It is exposed to the south of Afilou N'Khou, characterized by calcareous and sandstone formations, at the base is marked by a blue limestone formation with orthoceres (Fig.5 D, C) which marks the Silurian-Devonian passage. This series is characterized by the alternation of limestone and marly levels with intercalation of the sandstone 
levels (Fig. 5A), towards the summit, the series is characterized by sandstone beds affected by two families of diaclase (N80, N140) (Fig.5B).
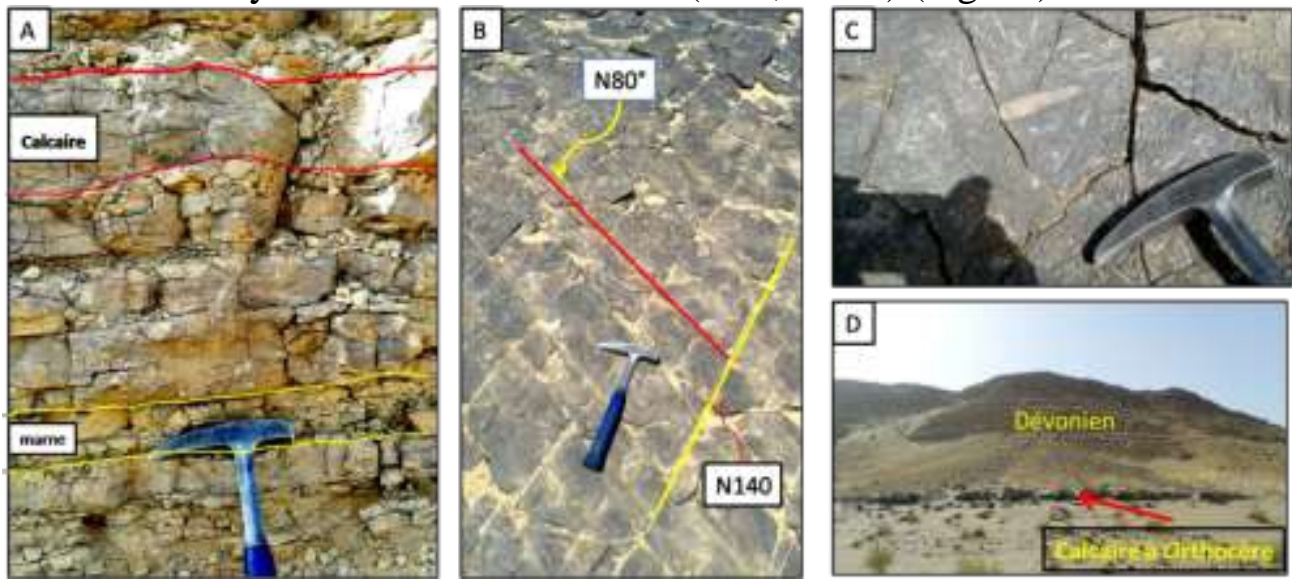

Figure 5. Devonian facies: carbonate series (A), sandstone diaclases (B), blue limestone with orthoceres $(\mathrm{C}, \mathrm{D})$.

\section{The Carboniferous}

Carboniferous sediments testify to a marked return of detritism following the Famennian sandstone. After a thick series of shales, the tendency becomes sandy (Baider, 2007). The Carboniferous formations closest to our study area are located about $10 \mathrm{~km}$ SE of the Bounhass Mine.

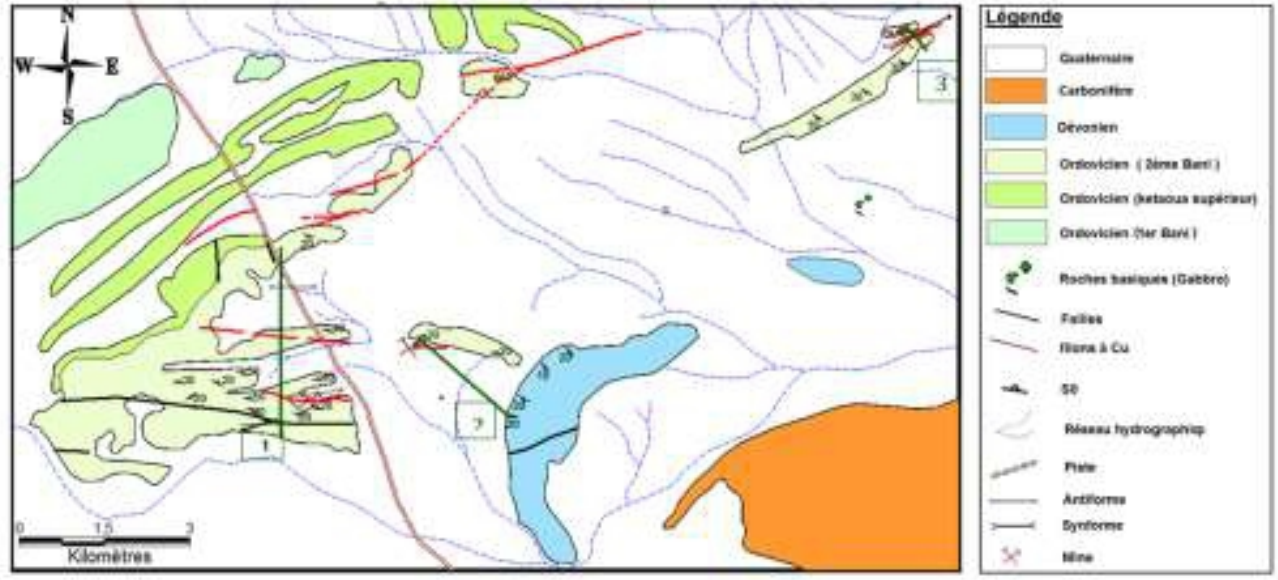

Figure 6. Geological map of the Oumjrane region modified and completed from the geological map of Toudgha, with rosette of the stratification, and location of three geological sections 1,2 and 3 .

\section{Structuration of the study area}

The geological structure of the Oumjrane region is represented by folds (Synclinaux and Anticlinaux) and faults which are generally the bearers of the copper mineralization, attributed during the Hercynian orogeny. 
We distinguish the main faults, which are generally oriented to Bunhass, Afounou N'khou, Bounhass, Bounhass Sud, Oumjrane Nord, Afilou N'Khou and NE-SW (Rich Merzoug) And Rich Merzoug) and the Tizi n'Mesmarin syncline.

Then three geological sections were made which represent the different structures of our region:

- N-S section of the Bounhass zone (Fig 8)

- NW-SE Cup of the Afilou N'Khou area (Fig 9)

- NW-SE section of the Rich Merzoug zone (Fig 10)

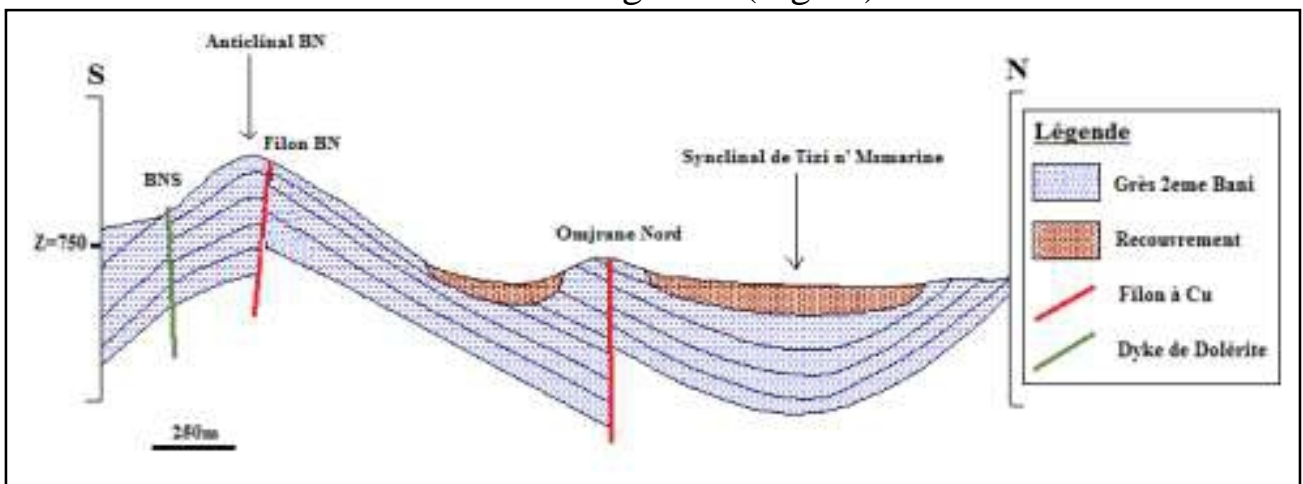

Figure 7. Geological section 1, Bounhass zone

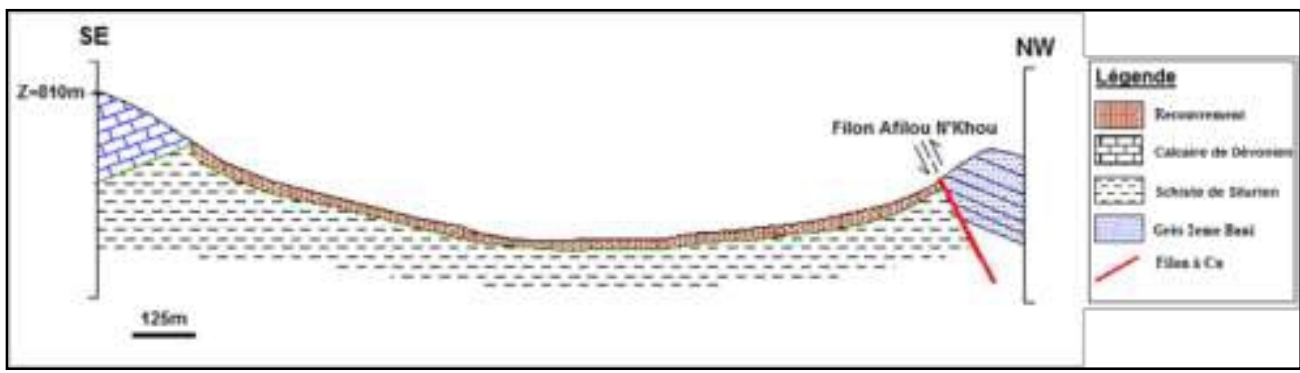

Figure 8. Geological section 2, Afilou N'Khou Zone

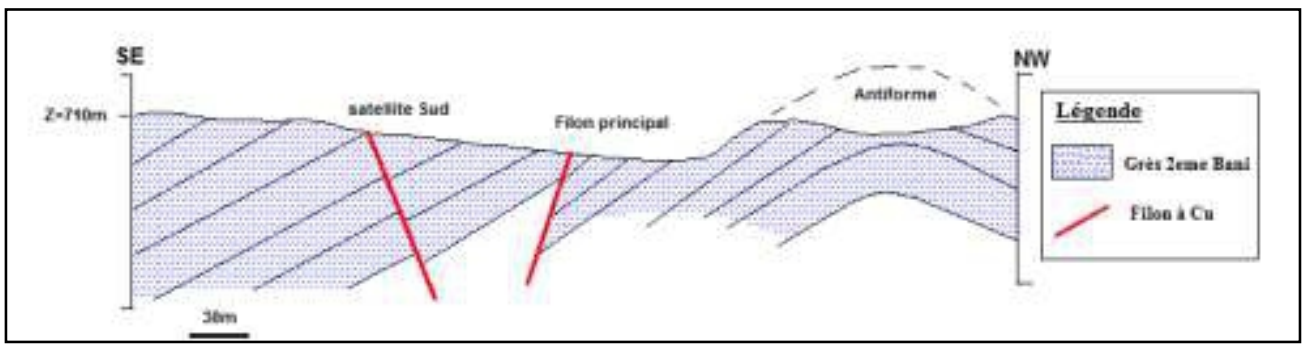

Figure 9. Geological section 3, Rich Merzoug zone 


\section{Magmatism of Oumjrane}

The magmatism in the region of Oumjrane is materialized by the establishment of the basic rocks (Dyke of doléritique, gabbro alkaline, and Basalte)

\section{Dolerite}

The South Bounhass Dyke is oriented E-W (N 90), outcrop over $100 \mathrm{~m}$ length and about $6 \mathrm{~m}$ of power. It is encased in the sandstones of 2 nd Bani, on the southern flank the Bounhass anticlinale. Fractionation affected the dyke at the carbonate-fired brick outcrop (Figure 10). The dyke is embedded in the sandstone-pelites with intercalaries (metric) of the black pelites, it shows a greenish color with a fine texture with phenocrysts at the edge, which becomes more and more fine towards the heart of the dyke. In some areas of the borehole, the dyke is characterized by the presence of centimetric enclaves with quartz filling, feldspars, calcite with a micrograined texture, it shows certain zonations with a mineralized pyrite outline towards the edges (Fig.12)

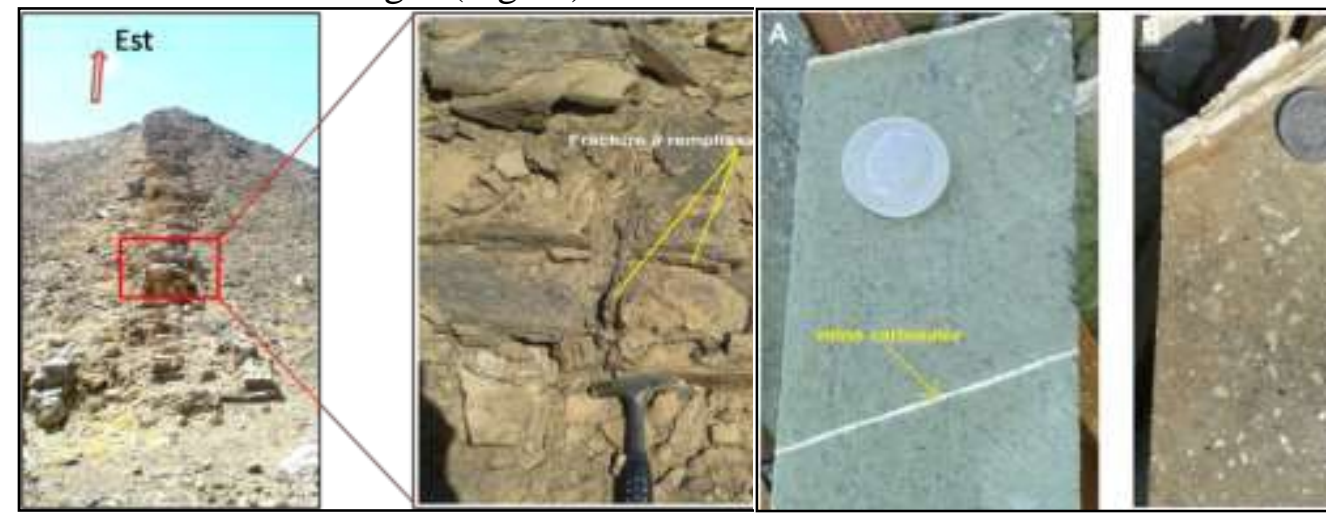

Figure 10. Dyke of dolerite to the south Bounhass (aspect in lighter) A) heart; B) border

A dissemination of pyrite is very abundant in these dolerites with traces of chalcopyrite. The state of alteration of dolerite is very advanced, materialized by a total sericitization of the plagioclases, and a chloritization of the biotites. The clinopyroxenes are totally transformed, the ghosts are recognizable. High fire losses (LOI), $8.9 \%$ hardly justified this intense alteration. 


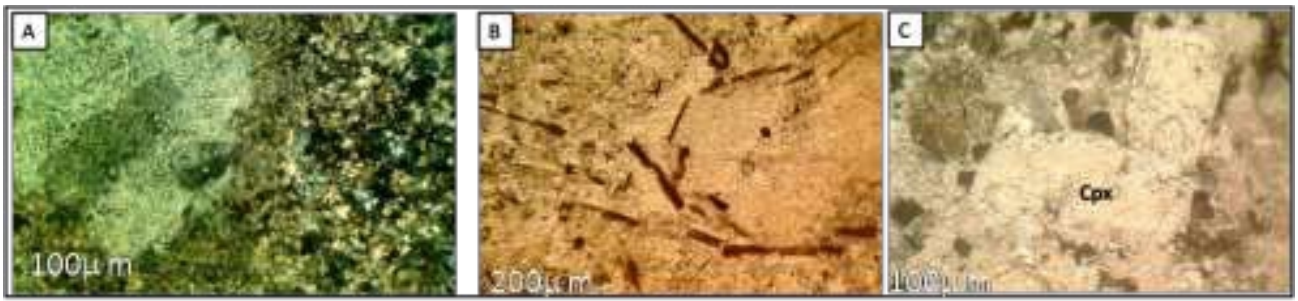

Figure 11. Microscopic view of PLA (A) vacuole dolerite, LP (B) needle biotite, Clinopyroxene phantom $(\mathrm{Cpx})(\mathrm{C})$

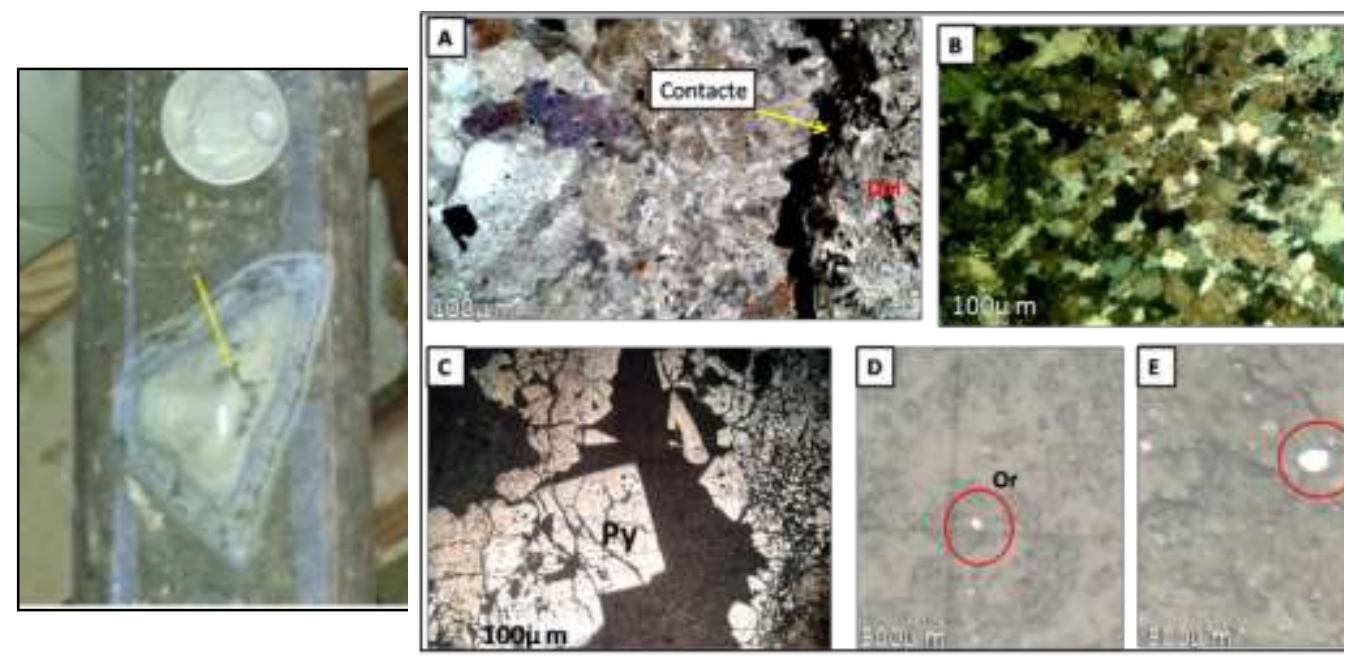

Figure 12. Macroscopic and microscopic view of the enclave: (A) Dolerite limit (Dol: Dolerite); (B) the heart of the enclave; (C) pyrite zone, (D and E) Disseminated native gold and silver.

\section{The gabbros}

More to the east, south of Afilou N'Khou, a magmatic pluton, macroscopically (BNS2 drill hole), shows a somewhat different aspect of South Bounhass, with a blackish color, a grainy texture, with shiny metallic minerals Are very abundant, and also to the fills of the microcracks.

The study of the BNS2 sounding (subvertical on the gabbroic intrusion) shows two facies: 1-The top shows a very altered (friable) ribbon aspect on a power of $10 \mathrm{~m}$, with brecciated textures (Fig. $14 \mathrm{C}$ ), crossed by carbonate late veins. 2- The heart of the intrusion is blackish with a gray texture composed of whitish and blackish minerals, intersected by quartzitic micro-veins. The gabbro to the south of Afilou N'Khou shows two main facies: 


\section{Fresh gabbros}

The microscopic study showed the presence of the following minerals: Cumulus minerals: represented by Olivine, Clinopyroxene and Plagioclases. Mineral inter-cumulus: represented by Plagioclases in slats, and Biotites. With the presence of apatites as accessory minerals, and opaque minerals (titaniferous magnetite). The presence of the titaniferous augite indicates an alkalinity of the magma (Fig. 13B). It is an alkaline gabbro with olivine, whose texture is notably grained (Fig. 13A). The state of alteration of this rock is not advanced. It is materialized essentially by a chloritisation of the biotites and a sericitization of the plagioclases.

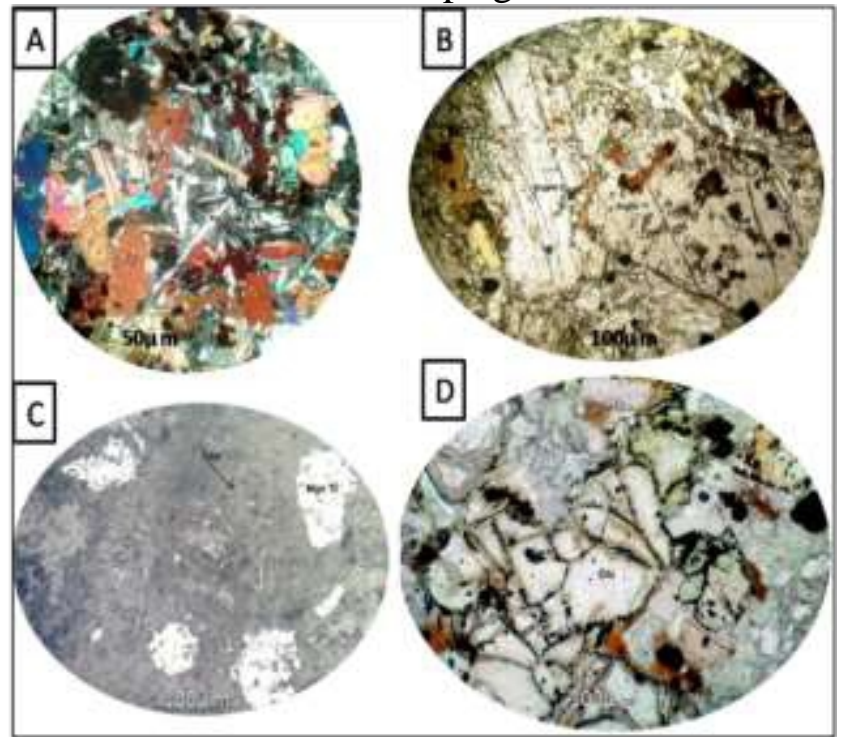

Figure 13. Microscopic view of Gabbro in LPA (A), titaniferous augite in LP (B), magnetite in reflex light (C), lattice calcopyrite and olivine fractures (D) .Cpy: chalcopyrite; Olv: olivine; Mgn: titaniferous magnetite

\section{Altered Gabbro}

The top of the gabbros is characterized by a highly altered carbonate zone (Fig. 14A). Three slides were made for a petrographic characterization, then our microscopic study showed that it is a very altered gabbro, whose mineralogy is as follows: amphibole, biotites in slats or xenomorphs, plagioclases, relics of pyroxenes, And opaque minerals (titaniferous magnetite), for minerals of alteration we distinguish chlorite and epidote (Fig. 14A).

The alteration of this rock is very important (Fig. 14A B and C), it is materialized by strong perivasive carbonation or in veins $(\mathrm{CaO}$ content $=$ $14.16 \%$ ). The very high fire loss (FP) 11.93\%) argued the high alteration intensity of our rock. This alteration is limited to these gabbro at $10 \mathrm{~m}$ depth (Fig.15), carbabation of gabbros at depth is little or no observed. 

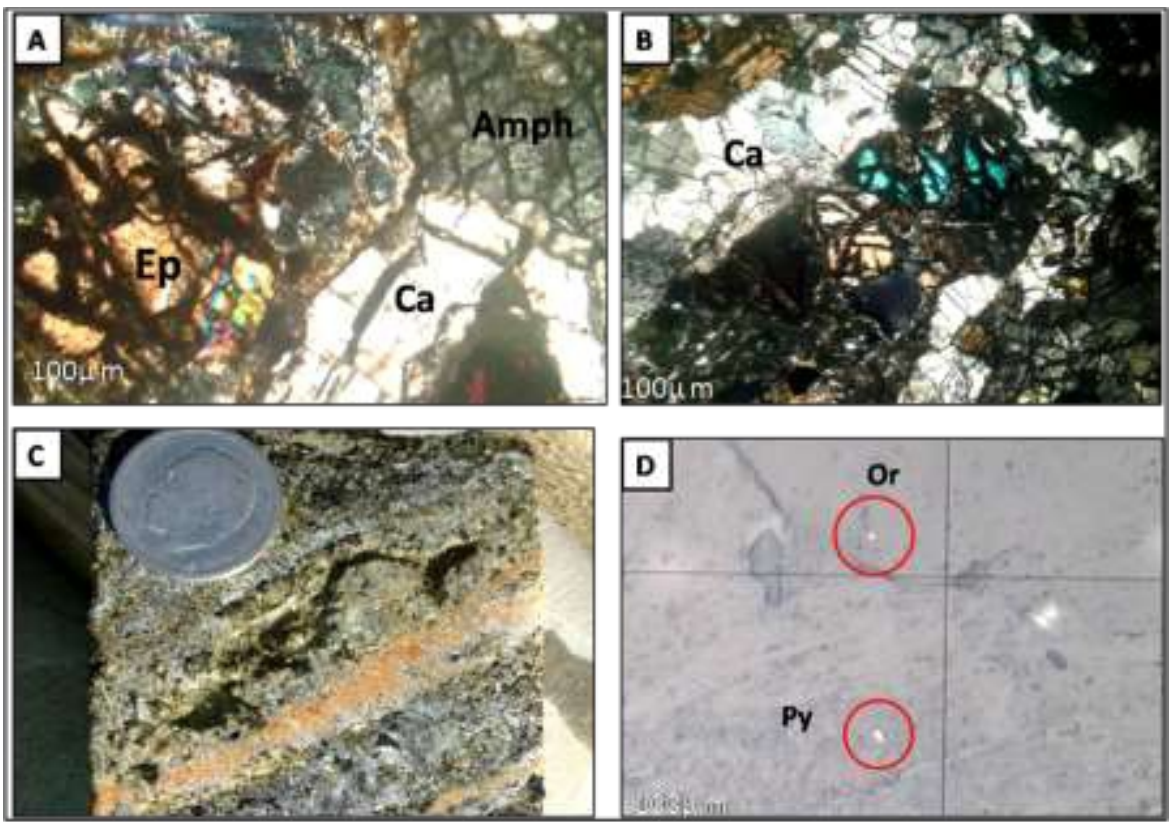

Figure 14. Microscopic view of altered gabbros (A, B), macroscopic view (C), gold and disseminated pyrite in calcite veins (D). Ca: calcite; Amph: amphibole; Epidotech; Py: Pyrite.

The source of calcite can only be justified by a contribution by meteoric waters from a carbonate sedimentation basin (the Dévonian carbonate series), following a brecciation of the mother rock (gabbro).

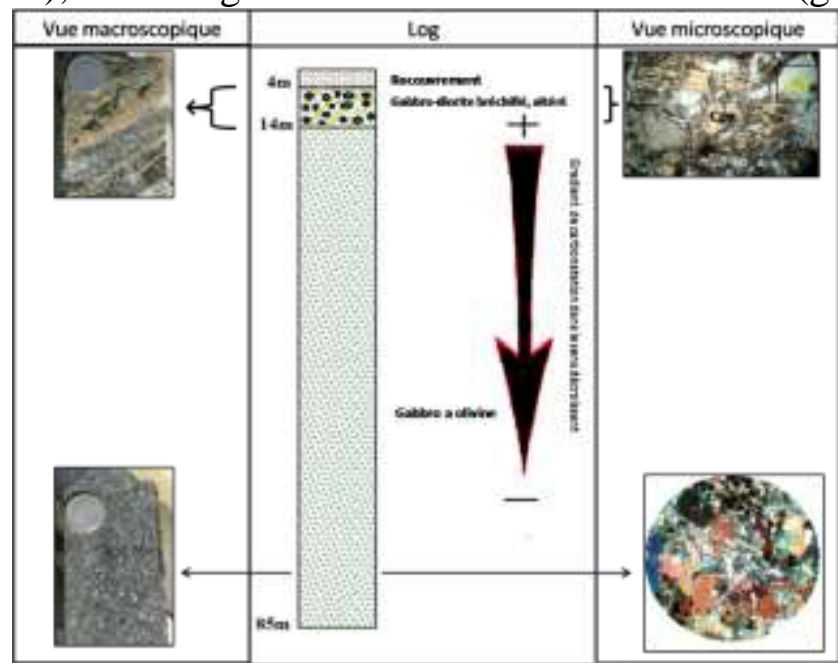

Figure 15. State of carbonate alteration of gabbros in the south Afilou N'Khou (drilling BNS2) 


\section{The Basalts}

To the south of Rich Merzoug at $3 \mathrm{~km}$ (coordinates: $\mathrm{X}=5.02191, \mathrm{Y}$ $=30.69580, \mathrm{Z}=695)$, magmatic rocks are flush with dome from 100 to $300 \mathrm{~m}$ in diameter, N70, and N100), the texture is particularly fine. The microscopic study of the basalts flushing south of Rich Merzoug, showed that it is a basalt whose primary mineralogy has undergone an almost total transformation due to alteration. It is essentially plagioclases, biotites, with clinopyroxene phenocrysts, presaging a porphyric microlitic texture. A very marked alteration has affected the basalts. It is materialized by a very large sericitisation of plagioclases, and a very dominant chloritisation of the clinopyroxene which can be justified by a circulation of a meteoric or hydrothermal fluid rich in calcite.

\section{Mineralization}

This part consists of studying the mineralization of copper seams of Rich Merzoug and Afilou N'Khou in order to define the main characteristics of the mineralization of our veins.

The Rich Merzoug deposit is located 12Km NE of the Bounhass Mine. Access to the mine is possible on a runway from the Bounhass Mine passing through the D'Afilou N'Khou mine. Lambert coordinates $(\mathrm{X}=$ 537072.84, $\mathrm{Y}=413364.74, \mathrm{Z}=701)$. Rich Merzoug's copper strand is embedded in a small anticlinal arch of the 2nd Bani sandstone, the stratification measures show a low dip $30^{\circ}$ to the south (southern flank), and an N60 direction. The mineralization consists mainly of sandstones and black pelites.

In the Rich Merzoug deposit, there are two N-oriented mineralized structures 60 with different dips. The dip main structure (variable), operated at the -60 and -40 levels. The South satellite structure with dip $60^{\circ}$ to $70^{\circ} \mathrm{N}$, operated at level -57 and -40 . The mineralization of Rich Merzoug is represented by two types:

- Primary mineralization: represented by sulphides of copper, iron and lead (chalcopyrite, pyrite, galena).

- Secondary mineralization: due to oxidation (malachite, azurite (rare), and native copper ...) observed at the -40 level.

The sampling was done according to levels for the purpose of studying the behavior of the mineralization at the vertical scale, from level 40 to level $-150 \mathrm{~m}$, in order to remove the main mineralized phases.

Level-40m: The study showed the following paragenesis : PyriteArsenopyrite-Chalcopyrite-Sphalerite.

According to a massive texture, chalcopyrite occurs in the form of large beaches in the quartzitic gangue, with pyrite and Arsenopyrite inclusions, whose pyrite is brecciated, fractured and chalcopyrite clogged. 
Sphalerite is rare in association with chalcopyrite, the presence of hematite, covellite and digenite (Cu9S5) comes in supergene stage due to the oxidation of chalcopyrite. Macroscopically malachite, azurite, native copper are observed in this level. The sericite originates from the alteration of the enclaves of black pelites (enclosing), carried by the vein during the rise of the hydrothermal fluids.

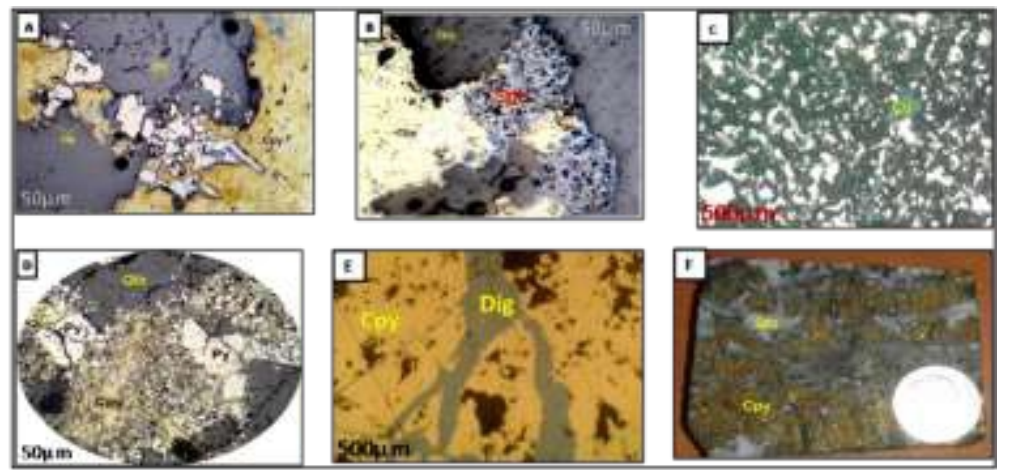

Figure. 16. Microscopic view by reflected light of the sample RM3 (A, B, C); Macroscopic view (D). Cv: covellite; Dig: digenite; Sph: sphalerite; Aspy: arsenopyrite; Py: pyrite; Cpy: chalcopyrite; Qtz: quartz.

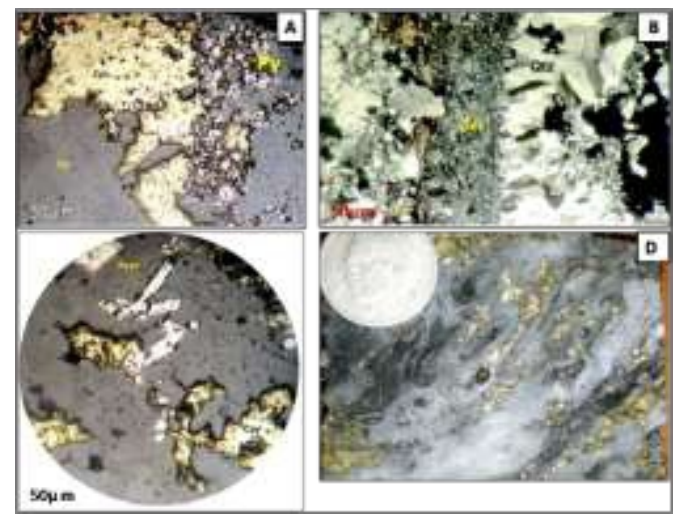

Figure 17. Microscopic view of blade RM6 (A, B, C), macroscopic view (D)

It is the area richest in copper with grades of up to $26 \% \mathrm{Cu}$ for the central part of the main vein at level -40 , and $7 \% \mathrm{Cu}$ for the extreme west of the south satellite

Level $\mathbf{- 5 7 m}$ : The microscopic study of this level was described according to two polished thin plates (RM1: East part and RM5: West part), it is therefore an arenopyrite - pyrite - chalcopyrite paragenesis, whose gangue is quartz, Siderite.The pyrite in this level is more abundant, it is brecciated and clogged (and in inclusion) by chalcopyrite. Chalcopyrite is also present in cracks that cross the pyrite (Fig. 18B). The texture is banded, composed of the chalcopyrite quartz ribbons which pass through the early siderite, some ribbons show a shear deformation which affects the 
mineralization (Fig. 18 D). Arsenopyrite is presented in sub-automorphic aggregates in quartz (Figure 18C), which is once brecciated, showing its anteriority to pyrite. A late-stage quartz stage, in microveins intersecting all the tapes, shows no mineralization (Fig. $18 \mathrm{~A}$ ).

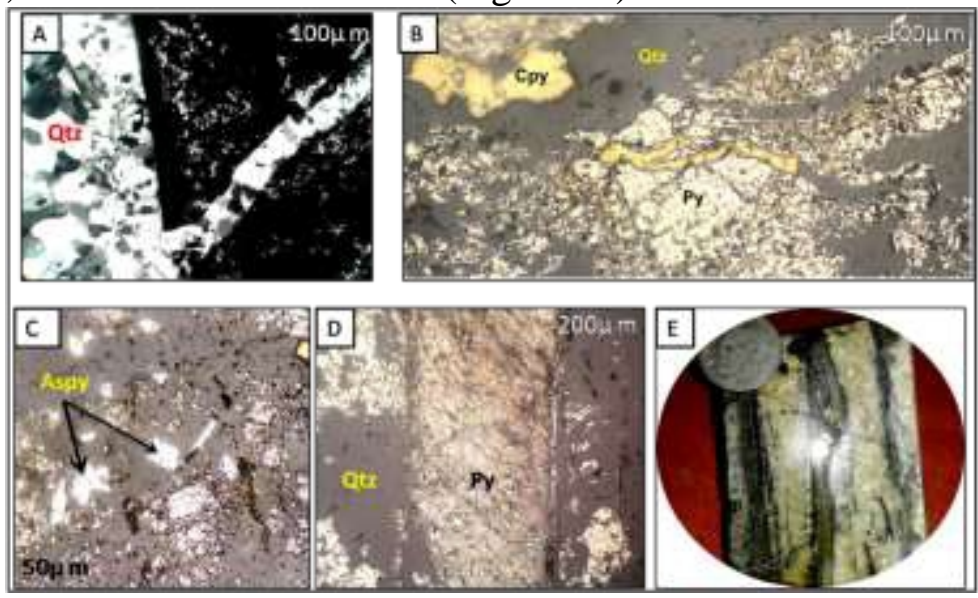

Figure 18. Microscopic view of the plate RM1 (A (transmitted light), B, C, D reflected light), macroscopic view (A).

Level -60 : For the eastern part it is essentially pyrite-galenachalcopyrite. The latter is most dominant in large ranges disseminated in quartz (Fig.19A), while pyrite is rare. The study of this plate shows the existence of two types of quartz, Qtz1 and Qtz2. The first quartz (Q1) microsacaroide which is mineralized, tends that the second (Q2) is little or not mineralized (Fig.19 B). The psodomorphosed galena in cerusite, is carried by the baritine quartz, it presents in ranges with inclusions of chalcopyrite (Fig.19 C)

The western part shows the paragenesis pyrite - arsenopyrite chalcopyrite, the gangue is essentially siderite quartz (Fig.20A). Quartz is the bearer of the mineralization. This zone shows a banded appearance (Fig.20 B) whose pyrite is brecciated and clogged with chalcopyrite.
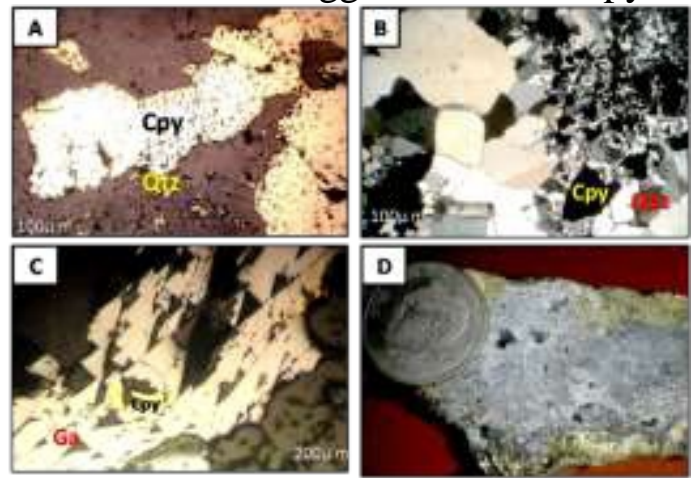

Figure 19. Microscopic view of the RM2 plate in reflected light (A, C), transmitted light (B), macroscopic view (D). Cpy: chalcopyrite; Qtz: Quartz; Ga: Galena. 

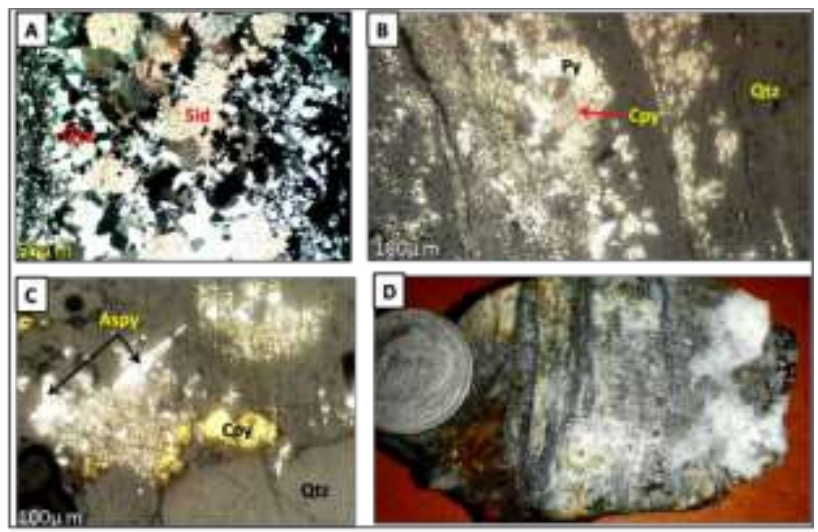

Figure 20. Microscopic view of the RM4 plate in transmitted light (A), reflected light (B, C), macroscopic view (D). Sid: siderite; Cpy: chalcopyrite; Py: pyrite; Aspy: arsenopyrite;

Qtz: Quartz

Level -90m : The macroscopic and microscopic study of this level, indicate two paragenesis :

- Pyrite - arsenopyrite - chalcopyrite - galena for the RM7 blade, in a disseminated texture pyrite is less brecciated than the higher levels, it is presented in aggregates included in chalcopyrite (Fig. 21A), in a gangue essentially formed of quartz . The presence of intense sericitization (Fig.21 C) is due to the presence of black pelite inclusions within the vein. At this level the appearance of sphalerite in association with chalcopyrite (Fig. 24 B) is noted, it is a little rare.

- Pyrite - chalcopyrite, whose chalcopyrite occurs in large disseminated ranges in quartz, with inclusions of pyrite. Sphalerite is not present at this level.
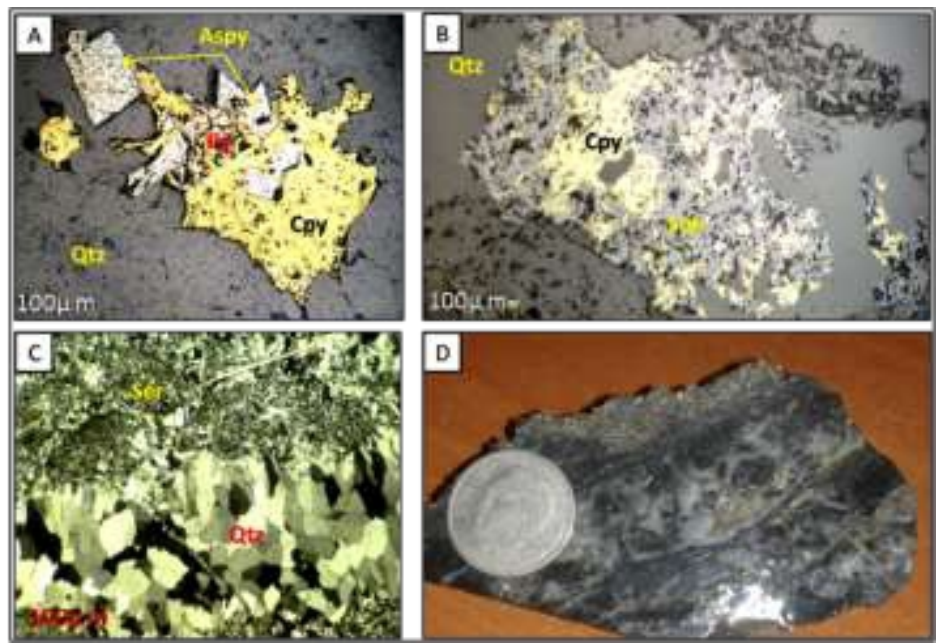

Figure 21. Microscopic view of the RM7 plate: reflected light (A, B); In transmitted light (C); Macroscopic view (D). Qtz: Quartz; Sér: Sericite; Py: Pyrite; Aspy: Arsenopyrite; Cpy: Chalcopyrite. 
Level -150: Represented by blade RM9 and RM10. It is always the same paragenesis with pyrite - arsenopyrite - chalcopyrite. The texture is disseminated represented by chalcopyrite ranges with inclusions of pyrite (Fig. 22A, B) always carried by a quartz-matrix. Automorphic to subautomorphic arsenopyrite is more abundant in this level, sometimes within the chalcopyrite. Substantially formed siderite quartz gangue is observed. It is generally the mineralized quartz ribbons that intersect the siderite (Figure 22A).

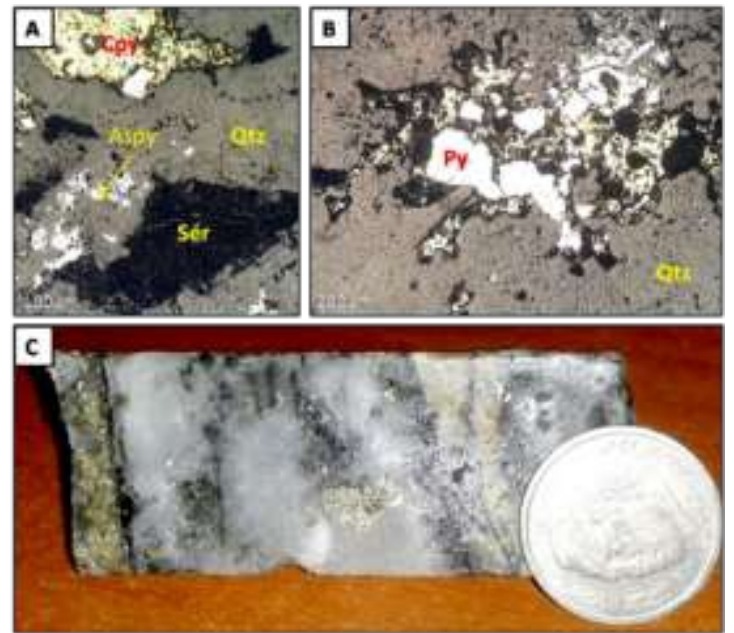

Figure 22. Microscopic view of the sample RM9 in reflected light (A, B), macroscopic view (C)

\section{Afilou N'Khou ore deposits}

The Afilou N'Khou deposit is located $3 \mathrm{~km}$ east of the Bounhass mine and $4 \mathrm{~km}$ north of the Douar Oumjrane. Lambert cordon ( $\mathrm{X}=$ 528693,39; $\mathrm{Y}=408042,39 ; \mathrm{Z}=713$, 67). Afilou N'khou vein is part of the Oumjrane E-W vein system. It is encased in a relatively large rejection fault which collapses the southern flank of an anticlinal fold consisting of sandstones of the 2nd Bani. The vein is embedded in the sandstones and argillites of the $2 \mathrm{nd}$ Bani powerful from $60-70 \mathrm{~m}$. The vein is included in a powerful grinding zone of 5 to $7 \mathrm{~m}$ with either silyl silicic schist or sandstone and fractured pelites from the 2nd Bani.

The mineralized structure of Afilou N'Khou of an N110 direction, with a dip $70^{\circ} \mathrm{N}$, is encased in the silurian schists and the sandstones of the 2nd Bani. The structure is quartz, siderite, where chalcopyrite presents itself in dissemination, and in centimetric ribbons. 


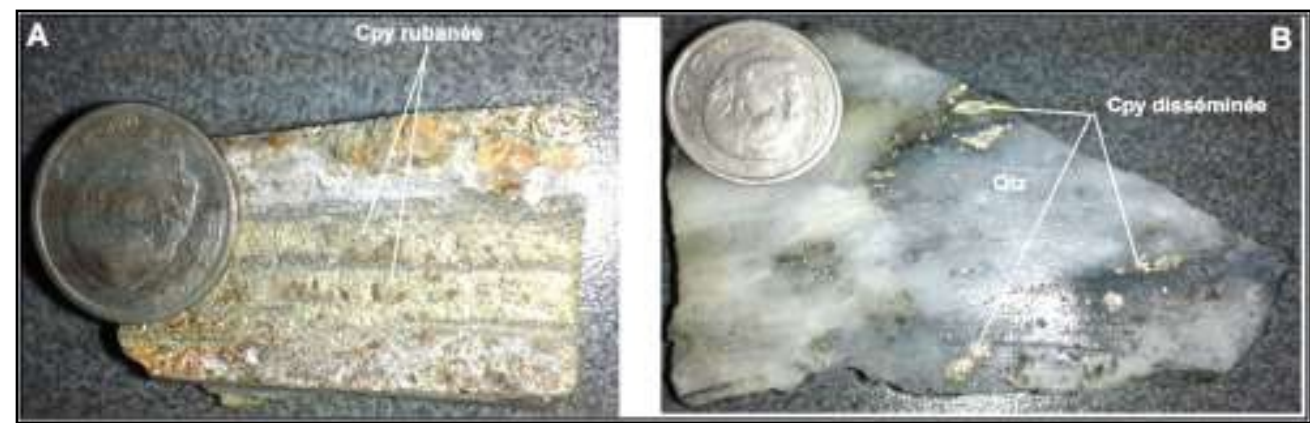

Figure 23. Afilou N'khou copper mineralization (Level -50), A) Banded Cpy; B) Cpy disseminated

For the vein of Afilou N'Khou it is the same hydrothermal stage 1, 2, 4 of which the paragenesis pyrite-arsenopyrite-chalcopyrite. The galena stage is not observable, the study of this vein has been made only from surface cuttings, whereas it requires a very precise sampling at the level of the vein in depth, to better account for the events Mineralisers in their geological context.
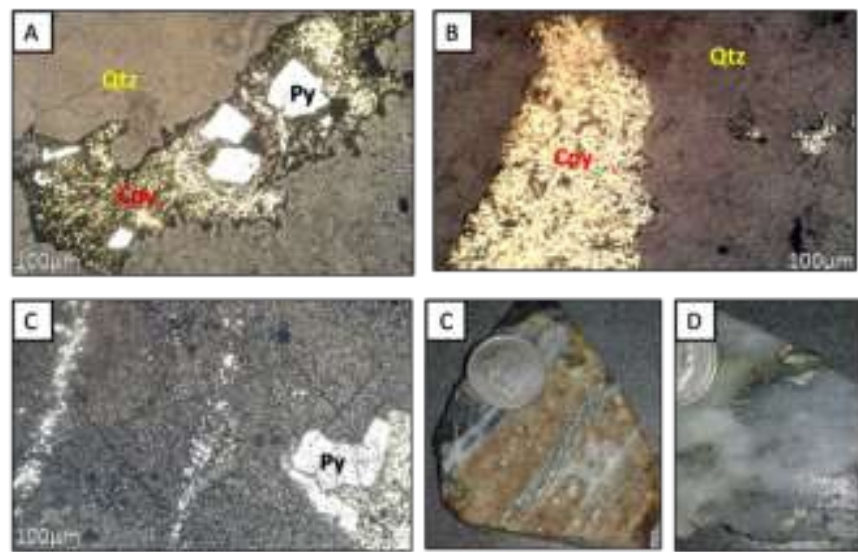

Figure 24. Microscopic view of some samples taken from the surface piles: (A): chalcopyrite ribbon with pyritic inclusions; B: chalcopyrite ranges; $(\mathrm{C})$ pyrite bandings; $\mathrm{C}$ : banded texture; D: disseminated texture

The mineralization of the district of Oumjrane is of the vein type to (Copper, Lead, Zinc). Which can be linked to a distant stage at the level of the Anti-Atlas during the Hercynian orogeny (situation at the northern end of the Zagora graben). The genesis of mineralization, followed two mineralizing events. A hypothermic hydrothermal event, responsible for the emplacement of sulphides, and the second event attributed to alteration and oxidation supergene. The mineralization genesis follows a succession of 4 hydrothermal stages: i) Stage 1: Calcite, Siderite; ii) Stage 2: Pyrite Arsenopyrite with quartz gangue; iii) Stage 3: Galena-Barytine and iv) Stage 4: Chalcopyrite - Sphalerite with quartz gangue. 


\begin{tabular}{|c|c|c|c|c|c|}
\hline & & \multicolumn{2}{|c|}{ Bréchification } & \multirow[b]{2}{*}{ Stade 4} & \multirow[b]{2}{*}{ Stade supergène } \\
\hline Minéral & Stade 1 & Stade 2 & Stade 3 & & \\
\hline Calcite/Sidérite & $\longrightarrow$ & & & & \\
\hline Quartz & & - & $\longrightarrow$ & $\longrightarrow$ & \\
\hline Pyrite & & $\Longrightarrow$ & & & \\
\hline \multicolumn{6}{|l|}{ Arsénopyrite } \\
\hline Chalcopyrite & & & & $\Longleftarrow$ & \\
\hline \multicolumn{6}{|l|}{ Galène } \\
\hline Sphalérite & & & -- & ---1 & \\
\hline \multicolumn{6}{|l|}{ Barytine } \\
\hline Covellite & & & & & n............. \\
\hline Hématite & & & & & -..... \\
\hline Cérusite & & & & & n..... \\
\hline Diéénite & & & & & n...... \\
\hline Arurite & & & & & - \\
\hline Malachite & & & & & n.t. \\
\hline Chalcocite & & & & & 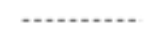 \\
\hline Cuivre natif & & & & & - \\
\hline
\end{tabular}

Figure 25: Paragenetic succession of Oumjerane district (Rich Merzoug's and Afilou Nkhou) copper deposits.

A Supegene Stage due to the oxidation of sulphides, represented in the upper zones of the veins. The placing of gabbros, dolerite, and basalt in the vicinity of veins, draws attention to the following question: what is the relationship with the mineralization? The presence of disseminated sulphides in these rocks does not directly lead to the conclusion that they are the source of mineralization, but chloritization of gabbros, dolerites and basalts is accompanied by mineralization, thus the most preserved silicate minerals contain mineralization disseminated sulphide, this is in favor of a remobilized magmatic pre-stock, and is concentrated during the hydrothermal phases. This remains to be confirmed by geochemical analyzes, mass balances, and isotopic analyzes of sulfur, oxygen, and lead, and fluid inclusions on mineralized quartz in order to approximate the geodynamic conditions of the installation Of the mineralization. From the figures below we can see the distribution of the Oumjrane district vein field in two main families E-W and NE-SW. According to a mineralization, the district of Oumjrane can be subdivided into two main zones: 
Western zone : Chalcopyrite-pyrite $(\mathrm{Cu}, \mathrm{Fe})$ with the Bounhass $(\mathrm{BN})$, Bounhass Nord (BNN), and Afilou N'Khou (AK) veins.)

Eastern Zone where the deposit of galena and barite $(\mathrm{Pb}-\mathrm{Ba})$ is observed in Rich Merzoug (RM) and then the barite which becomes more dominant in the vein of Boukerzia (BK).)

We can see that the Oumjrane sector shows a horizontal zonality, which would reflect a chemical and thermal gradient with: a western zone with $\mathrm{Cu}-\mathrm{Fe}$ (sulphides) that would be a hot zone and an east zone with $\mathrm{Pb}-\mathrm{Ba}$ (sulphides-sulphates ), Which would be less warm. This gradient from west to east could indicate the direction of the fluid circulations, which is from the west (warm) to the east (cold).

This zone, which marks the passage between sulphides and sulphates, constitutes the favorable conditions for the deposition of gold, which could guide the exploration of $\mathrm{Cu}-\mathrm{Pb}$ towards an exploration of $\mathrm{Au}$, east and northeast of the sector. Namely the Boukerzia area.

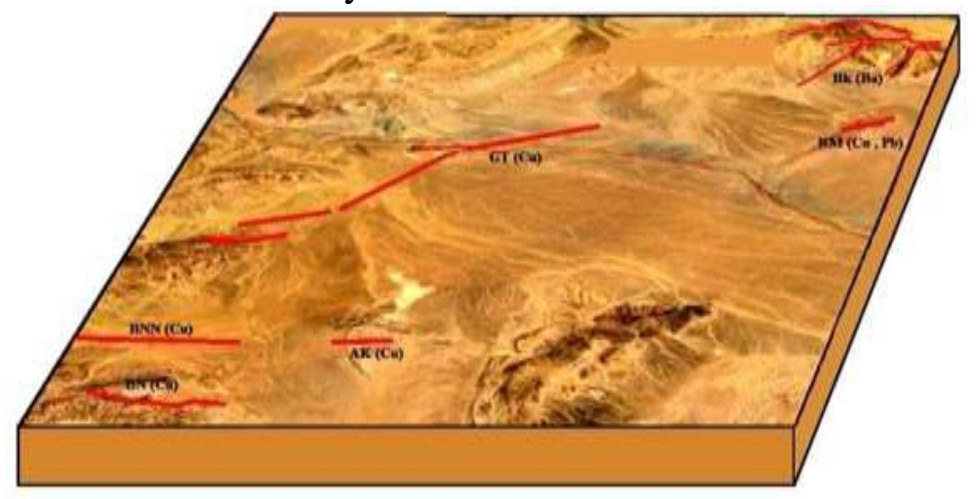

Figure 26 : Block diagram showing the spatial evolution of the mineralogical and chemical zonation of the Oumejerane deposit

\begin{tabular}{|c|c|c|}
\hline Ore deposit & mineralization & Direction \\
\hline BN (Bounhass) & Cu & \multirow{2}{*}{ E-W } \\
\cline { 1 - 1 } & & \\
\cline { 1 - 1 } BNN (Bounhass Nord) & & \\
\cline { 1 - 1 } AK (Afilou N'Khou) & & \multirow{2}{*}{ NE-SW } \\
\hline RM (Rich Tibert) & & \\
\hline BK (Boukerzoug) & Cu-Pb-Ba & \\
\hline
\end{tabular}

\section{Conclusion}

The research that has been the focus of this study has been largely devoted to the copper strands of Rich Merzoug and Afilou N 'Khou, with a parallel study of the magmatic and sedimentary rocks. The magmatic rocks show different facies, from east to west we distinguished: 
- Dolerite;

- Gabbro alkaline to olivine;

- Basalt.

The petrographic study under the optical microscope revealed a strong alteration of the magmatic rocks. This alteration was materialized by chloritisation, sericitization and carbonation. The latter is very important at the top of the gabbro at a depth of $14 \mathrm{~m}$. Indeed, very high carbonation has been observed with the naked eye as well as with the microscope, it can be linked to a circulation of meteoric or hydrothermal fluids rich in carbonates. It is represented by veins of calcite. The gabbro below this level is less altered, only a rare sericitation and chloritisation were noted.

The magmatism in the sector of Oumjrane, poses a problem of age:

In the literature the alkaline magmatism has been attributed to the Cambrian and the rest is post-Cretaceous, however, the fields of our area are Ordovician and no magmatic manifestation is known in this age. A more advanced petrological and geochemical study, combined with radiochemical dating, would be interesting. The mapping study of the zone allowed us to define the main facies and enclosing structures of the mineralization:

- Bounhass Anticlinal;

- Syndrome of Tizi n'Mesmarin;

- Anticlinal of Afilou N'Khou;

- Anticlinal of Rich Merzoug.

These E-W-based plicative structures would result from an N-S tectonic stress during Hercynian orogeny. These three structures, consisting essentially of the quartzite sandstones attributed to the series of the second Bani of Ordovician age, represent the casing of the mineralized veins: Bounhass vein, Northern Oumjrane, Afilou N'khou, Rich Merzoug, Gara Tibert, and Boukerzia. Our study was focused on the example of Rich Merzoug vein and Afilou N'Khou, the two respective NE-SW, EW directional veins, following two mineralizing events: event 1 , hydrothermal hypogen and Event 2, meteoric supergene, responsible for the alteration of sulphides.

\section{Hydrothermal event}

Responsible for sulphide deposition in four main stages: i) Stage 1: calcite Siderite; ii) Stage 2: pyrite, arsenopyrite; iii) Stage 3: galena - barite; iv) Stage 4: with chalcopyrite. A late-stage quartz stage of non-mineralized microveins crosses the whole. 


\section{Supergene event}

Responsible for the oxidation of copper sulphides generally represented in the upper levels by malachite, azurite, hematite, covellite, digenite, native copper.

By combining our geological and metallogenic study of the Oumjrane district, we can conclude that it is a mineralization of the vein type which is integrated into the $\mathrm{Cu}-\mathrm{Pb}-\mathrm{Zn}$ system. This mineralization can probably be related to the two tectonic events characterizing the geodynamic history of the Anti-Atlas, the first major responsible for placing the $\mathrm{Cu}-\mathrm{Pb}$ $\mathrm{Zn}$ mineralization at the level of the Hercynian basement and the second Atlas, responsible for the remobilization and reconcentration of copper at the EW (Bounhass, Afilou N'Khou) and NE-SW (Rich Merzoug) structures. We have also demonstrated a geochemical and mineralogical zoning - passing from chalcopyrite / pyrite to galena / barytine - and chemical - passing from $\mathrm{Cu} / \mathrm{Fe}$ to $\mathrm{Pb} / \mathrm{Ba}-$ which would reveal a thermal gradient. This would likely give new prospects for mining prospecting in the Oumjrane mining district.

\section{References:}

1. BAÏDDER,L. (2007). Structuration de la bordure septentrionale du Craton Ouest Africain du Cambrien à l'actuel: Cas de l'Anti Atlas oriental du Maroc. Thèse d'état ES-Sciences, Université Hassan II.

2. BURKHARD, M., CARITG, S., HELG, U., ROBERT-CHARRUE, Ch. \& SOULAIMANI, A. (2006).Tectonics of the Anti-Atlas of Morocco. Comptes Rendus Geoscience, 338, 11-24.

3. CHOUBERT, G. (1943): Quelques réflexions sur la términaison orientale de l'Anti-Atlas. Bull. Soc. Sciences Naturelles du Maroc, pp. 67-79.

4. FETAH h. (2015). Contribution à l'étude géologique et métallogénique des filons cuprifères de Rich Merzoug et d'Afilou N'Khou du gisement d'Oumjrane (Anti-Atlas Oriental). Master GARME, Université Cadi ayyad, 2015. 77 p.

5. HELG, U., BURKHAND, M., CARIGT, S., ROBERT-CHARRUE, Ch., 2004. Folding and inversion tectonics in the Anti-Atlas of Morocco. Tectonics 23, 1-17.

6. KHARIS A. , AISSA M. , BAIDDER L., OUGUIR H. , MAHDOUDI M.L. , ZOUHAIR M. \& OUADJOU A. (2012). Oumjrane-Bou Nahas, une mine de cuivre dans l'Ordovicien supérieur du Maïder / Oumjrane-Bou Nahas, a Copper Mine in the Maider Upper Ordovician Quartzites. 2012. LES PRINCIPALES MINES DU MAROC/ Main Mines of Morocco. NOTES ET MÉMOIRES DU SERVICE GÉOLOGIQUE N ${ }^{\circ} 564$ NOUVEAUX GUIDES GÉOLOGIQUES ET MINIERS DU MAROC. Volume 9. 
ÉDITIONS DU SERVICE GÉOLOGIQUE DU MAROC RABAT 2011. pp 65-72.

7. MICHARD A, SADDIQI O, CHALOUAN A, FRIZON DE LAMOTTE D (2008) Continental Evolution: The Geology of Morocco. Structure, Stratigraphy, and Tectonics of the AfricaAtlantic- Mediterranean Triple Junction. Springer-Verlag, Berlin Heidelberg 116: 404 p. 